\title{
Amando Céspedes Marín: el intelectual tras el lente y el hacedor de identidades en el papel
}

\author{
Marcela Otárola-Guevara* \\ https://orcid.org/0000-0003-0627-4275
}

Recibido: 02 de enero de 2020 • Aceptado: 30 de enero de 2020

\section{Resumen}

La fotografía es un recurso documental importante en la interpretación de la realidad sociocultural; por esta razón, en este artículo se recurre a una parte del acervo del fotógrafo Amando Céspedes Marín para elucidar un planteamiento de identidad costarricense, creado dentro del marco de la conmemoración del primer centenario de la independencia de la República. Los Estudios Culturales conforman la plataforma teórica a partir de la cual se analizan 20 fotos (diez con temas urbanos y diez con temas rurales) elaboradas entre 1905 y 1923. Metodológicamente, las imágenes se escrutan mediante preguntas pertinentes a la narrativa; finalmente, se formula una reflexión en la cual se revela una identidad basada en lo enunciado y lo omitido, labor que involucra al experto en mención. ${ }^{1}$

Palabras clave: Identidad cultural, discurso fotográfico, representación sociocultural.

\footnotetext{
* Magister Scientiae en Historia Aplicada de la Universidad Nacional (UNA), de Costa Rica. Licenciada en Arquitectura de la Universidad de Costa Rica (UCR), de Costa Rica. Doctoranda del doctorado de Estudios de la Sociedad y la Cultura de la UCR. Profesora e investigadora de la Escuela de Historia, Facultad de Ciencias Sociales de la UNA, de Costa Rica. Correo electrónico: zaida.otarola.guevara@una.cr

${ }^{1}$ La autora agradece al Dr. Antonio Álvarez Pitaluga por las recomendaciones hechas a la versión preliminar de este escrito y a las personas evaluadoras quienes, con sus observaciones, lo enriquecieron.
} 
Amando Céspedes Marin: the intellectual behind the lens and the maker of identities on paper

\begin{abstract}
Photography is an important documentary resource when interpreting the sociocultural reality; for this reason, in this article, it is taken into account a portion of the work background of the photographer Amando Céspedes Marín to explain an approach of the Costa Rican identity, proposed within the framework of the commemoration of the first centenary of the Republic's Independence. The Cultural Studies constitute the theoretical platform to analyze 20 photos (ten related to urban themes and 10 related to rural ones) created between 1905 and 1923. Methodologically, the images are scrutinized through pertinent questions to the narrative. Finally, there is a reflection that reveals an identity based on the stated and the omitted, work done by the expert Céspedes Marín.
\end{abstract}

Keywords: Cultural identity, photo speech, sociocultural representation.

\title{
Amando Céspedes Marin: l'intellectuel derrière la lentille et l'auteur d'identités sur le papier
}

\section{Résumé}

La photographie est une ressource documentaire importante dans l'interprétation de la réalité socioculturelle; c'est pourquoi cet article fait recours à une partie de l'acquis du photographe Amando Céspedes Marín afin d'élucider l'approche d'identité costaricienne, conçue dans le cadre de la commémoration du premier centenaire de l'indépendance de la République. Les Études Culturelles constituent la base théorique de l'analyse de vingt photos (dix rapportées aux sujets urbains et dix concernant les sujets ruraux) élaborées entre 1905 et 1923. En ce qui concerne la méthodologie, les images sont examinées à travers des questions pertinentes au récit. Finalement, on présente une réflexion qui révèle une identité fondée sur ce qui a été énoncé et ce qui a été omis, dont l'expert mentionné a fait partie.

Mots clés: Identité culturelle, discours photographique, représentation socioculturelle. 


\section{Introducción}

Las imágenes constituyen un recurso importante en la construcción simbólica; por esta razón, interesa estudiar las fotografías de Amando Céspedes Marín, como herramienta en la representación identitaria de Costa Rica en su primer centenario como nación independiente.

Precursor de la radiodifusión, y destacado fotógrafo, en 1923 efectuó un recorrido por parte del territorio nacional, gracias a una expedición organizada por el Congreso de la República en marzo y a una gira pastoral diocesana en mayo, el cual le permitió captar imágenes rurales que compiló en dos álbumes de fotos titulados: Costa Rica en su centenario 1921. Fotografías del viaje a Buenos Aires de Térraba; y Crónicas de la visita oficial diocesana al Guatuso.

Importantes acontecimientos motivaron la realización de tales viajes; entre ellos que la expedición del Congreso se organizó para exhumar los cuerpos y realizar las honras fúnebres de los Mártires de Buenos Aires: Rogelio Fernández Güell y algunos de sus correligionarios, quienes lucharon contra el régimen dictatorial de Federico Tinoco y murieron en Buenos Aires, Puntarenas, durante una refriega contra militares gobiernistas. Tinoco fue derrocado y le sucedieron Francisco Aguilar Barquero (temporalmente) y Julio Acosta García, este último quien, legitimado como presidente, al inicio de los años veinte debió afrontar la guerra contra Panamá y una grave crisis socio económica caracterizada por la falta de vivienda, huelgas y desocupación laboral ${ }^{2}$.

Por otra parte, la gira pastoral obedece a un hecho acaecido en el ámbito eclesial. En 1921, como resultado de la bula Praedecessorum decretada por el papa Benedicto $\mathrm{XV}$, se crea la provincia diocesana de Costa Rica, así San José pasa a ser arquidiócesis, mientras que Alajuela asume la posición de diócesis y Limón la de vicariato. La asunción de tales rangos implicó que el prelado de cada uno de ellos vigilara por la región que le correspondía administrar y, para ello, debían realizar giras pastorales ${ }^{3}$. Para acatar esta norma, Antonio del Carmen Monestel y Zamora, primer obispo diocesano de Alajuela, emprendió su primera visita a Guatuso, Los Chiles, Upala y el Río San Juan ${ }^{4}$, para esto se llevó a Céspedes Marín, quien dejó testimonio visual de ella.

Las embrionarias cabeceras decimonónicas de los cantones vallecentralinos de Heredia, San José y Cartago han sido ampliamente fotografiadas, pero son pocas las imágenes de los poblados de su periferia y de las provincias costeras; de allí la relevancia de estudiar imágenes de la ruralidad y contraponerlas con las citadinas para así obtener una visión más integral del país. Complementariamente, las imágenes urbanas elegidas son del cantón central de Heredia, domicilio del fotógrafo

${ }^{2}$ Eugenio Rodríguez Vega, Biografía de Costa Rica (San José: Editorial Costa Rica, 1980), acceso: 01 de junio de 2020, https://es.scribd.com/read/299531694/Biografia-de-CostaRica\#

${ }^{3}$ Ronald Eduardo Díaz Bolaños, «El estudio de la historia de la meteorología a través de las crónicas de Visitas Pastorales en Costa Rica (1850-1921)», Revista Estudios especial (2019): 26, doi: 10.15517/RE.V0I0.36264.

4 «Monseñor Dr. Antonio del Carmen Monestel y Zamora. I Obispo Diocesano (Del 14 de Agosto de 1921 al 8 de Octubre 1937)», Diócesis de Alajuela, acceso: 01 de junio de 2020, http://www.diocesisdealajuela.org/mons.-monestel.html 
y sitio que, en los últimos años del siglo XIX e inicios del XX, mostró un crecimiento de la infraestructura urbana, debido al apoyo político gubernamental a una zona que se destacó por una alta productividad agrícola cafetalera.

Las fotos de Céspedes Marín, junto con la de otros colegas coetáneos, han constituido un importante acervo documental que revela una idiosincrasia costarricense desde distintas perspectivas; no obstante, este fotógrafo se diferenció por retratar espacios urbanos y rurales, los cuales ilustran diversas interacciones que coadyuvaron a forjar la patria en los albores del siglo XX, una vez rebasada la época del Estado liberal finisecular en la que se impulsaron importantes transformaciones culturales.

¿Cuál es la imagen de Costa Rica tras un siglo de vida independiente? Es la interrogante central que orienta este escrito; más, como complemento, cabe inquirir adicionalmente: ¿Cuál es la identidad que se refleja en las fotografías? ¿Cuáles valores se proyectan en ellas y de dónde proceden? Así, tras estos cuestionamientos, el principal objetivo que se traza es establecer la imagen de Costa Rica a un siglo de haberse constituido como nación soberana; meta que involucra revelar una identidad devenida de la cosmovisión del fotógrafo en cuestión.

\section{Estado de la cuestión}

El uso de la fotografía está registrado en artículos y libros cuyos autores destacan su importancia como documento histórico. Se recoge aquí la selección de un grupo de escritos, la mayoría publicaciones en revistas científicas, cuyos autores tratan la fotografía como un recurso que faculta el acercamiento a un contexto social y conciben al fotógrafo como un mediador entre la realidad y la representación, dado que otorga un significado a la obra de acuerdo con su subjetividad.

Eva Martín Nieto ${ }^{5}$ comparte la premisa anterior, además agrega que la fotografía es una representación y, por ende, una construcción social creada mediante los artificios tecnológicos de un sujeto (el fotógrafo), quien plasma su cosmovisión en la obra. Desde esta misma perspectiva, Bernardo Riego ${ }^{6}$ establece que el estudio de la fotografía debe trascender su apariencia visual y, por ello, debe trabajarse como un «mapa de significados», porque constituye un elemento de representación social; de seguido, Riego procede a analizar un grupo de imágenes entre 1860 y 1890 para determinar los valores proyectados en ellas.

Consciente del papel que juega el fotógrafo en la creación de la imagen, Alberto del Castillo Troncoso ${ }^{7}$ recoge los testimonios de fotoperiodistas que cubrieron la masacre de Tlatelolco, acontecida en México en 1968 y, junto con sus imágenes, lleva a cabo un escrito que constituye la materialización de una premisa fundamental en su quehacer investigativo: la fotografía es un recurso fundamental para la

5 Eva Martín Nieto, «El valor de la fotografía. Antropología e imagen», Gazeta de Antropología 21 (2005): 1-4, acceso: 01 de junio de 2020, https://www.ugr.es/ pwlac/G21_04Eva_Martin_Nieto.html

${ }^{6}$ Bernardo Riego, «La imagen fotográfica como un mapa de significados: el caso del estudio fotográfico, un espacio para la representación social» (ponencia, Ayuntamiento de Girona, noviembre 1994).

${ }^{7}$ Alberto del Castillo Troncoso e Instituto Mora, «Los fotógrafos, la memoria y el 68 en México», Artelogie 7 (2015): 1-21, doi: 10.4000/artelogie.1102. 
elaboración de la memoria porque «...trasciende lo individual para construir una referencia colectiva y elabora relatos que posibilitan la identidad de grupos sociales» ${ }^{8}$.

José Muñoz Jiménez ${ }^{9}$ también conceptualiza la fotografía como un reservorio de memoria y precursor de identidad; por ello analiza fotografías de la comunidad de Fez en Marruecos, en ellas observa la reproducción de imaginarios asociados al colonialismo en motivos patrimoniales edilicios. Tal manejo intencionado de la fotografía también es abordado por Beatriz de las Heras y Víctor Mora ${ }^{10}$, quienes analizaron el acervo del fotógrafo Martín Santos Yubero, quien retrató eventos de la Guerra Civil Española (1936), para demostrar el uso de la foto como medio de comunicación entre las autoridades y los ciudadanos; acto que permitió crear memorias y desmemorias ${ }^{11}$.

El empleo instrumental de la fotografía también es discutido por Thelma Camacho Morfín ${ }^{12}$ y usa, como sustento para su disertación, el estudio del contenido fotográfico de los álbumes de la fábrica mexicana de cigarros «El buen tono», cuyo propietario elaboró dos compendios de imágenes: uno publicitario y otro gerencial (de uso exclusivo para sus directivos). En ellos la autora dilucida las intenciones del propietario, su ideario católico social y sus redes sociales.

Complementariamente, Alzira Tude de Sá afirma que la fotografía es una representación: «una cosa que está en lugar de otra» ${ }^{13} \mathrm{y}$, para su comprensión, se requiere analizar los factores ideológicos, socioculturales e históricos que la determinan, de allí que enuncie que la foto es un documento social e instrumento para la investigación científica, tesis que aplica al examinar los registros fotográficos de objetos personales del escritor Jorge Amado.

En el ámbito local se encuentra un artículo de Guillermo Brenes Tencio ${ }^{14}$, quien trata el inicio de la fotografía en Costa Rica a través del estudio de anuncios en periódicos, los cuales ofertan servicios fotográficos. Describe el contexto histórico y social bajo el cual, en el siglo XIX, en San José se instala un grupo de fotógrafos, la mayoría extranjeros, y, como secuela de su trabajo, insta a investigar la fotografía como parte de la Historia Cultural, veta poco explorada en las universidades.

\footnotetext{
${ }^{8}$ Ibíd., parr. 4.

9 José Muñoz Jiménez, «Photography, memory and identity», Revista de Comunicación de la SEECI 49 (2019): 123-140, doi: 10.15198/seeci.2019.49.123-140.

${ }^{10}$ Beatriz de las Heras y Víctor Mora, «Retratando el Madrid de la Guerra Civil. Santos Yubero en el Archivo Regional de la Comunidad de Madrid», Revista General de Información y Documentación 242 (2014): 343-371, doi: 10.5209/rev_RGID.2014.v24.v2.47404.

${ }^{11}$ Ibíd., 345.

12 Thelma Camacho Morfín, «Los álbumes de "El Buen Tono": fotografía y catolicismo social (México, 1894-1909)», Boletín americanista 71 (2015): 77-96, acceso: 01 de junio de 2020, https://dialnet.unirioja.es/servlet/articulo?codigo $=5503116$

${ }^{13}$ Alzira Tude de Sá, «A imagem fotográfica como representação e documento: um estudo a partir das fotografias de objetos da sala de visitas do escritor Jorge Amado», Inf.\&Soc.:Est. 28 (2018): 91-108, acceso: 01 de junio de 2020, https://periodicos.ufpb.br/index.php/ies/article/view/37898/19695

${ }^{14}$ Guillermo Brenes Tencio, «La alborada de la fotografía en Costa Rica: 1848-1869. Una contribución documental», Revista de Ciencias Sociales 113-114 (2006): 156-167, acceso: 01 de junio de 2020, https://revistacienciassociales.ucr.ac.cr/images/revistas/RCS113_114/12BRENES.pdf
} 
Por otra parte, Florencia Roa Gutiérrez y Alejandra Chaverri Álvarez ${ }^{15}$ retoman, en el libro: Las fotos de mi tata Mario Roa: Costa Rica (1936-1946), el legado del fotoperiodista Mario Roa, quien laboró para el Diario Costa Rica y se caracterizó por una sensibilidad social, claramente expresada en los motivos de sus imágenes, muchas de ellas con el ser humano segregado como motivo central. El texto es rico en imágenes, sin párrafos alusivos que sesguen la mirada del lector, acto que revela la intención del uso de la imagen como un texto en sí mismo.

Finalmente, San José, la capital costarricense, es el tema central de un compendio de fotografías y textos literarios que Flora Ovares y Margarita Rojas reunieron en $L a$ ciudad imaginada ${ }^{16}$, documento que muestra esta localidad a través de seis temáticas: transeúntes, lugares de encuentro, nostalgias, calles y tinieblas; en ellas se muestra la cotidianidad diversa de sus habitantes, resultante de diferentes coyunturas históricas.

Un balance general del material presentado expone dos temas recurrentes: el uso de la fotografía como mecanismo para forjar memoria; y el del rol del fotógrafo como intérprete de la realidad, acto que en algunas ocasiones estuvo al servicio de élites militares, empresariales y políticas. Asimismo, se entrevé, en las propuestas de los autores citados, la necesidad de impulsar el uso de la fotografía como fuente historiográfica documental y estimular el desarrollo de la Historia Cultural; deudas académicas que se apreciaron en la búsqueda de los insumos para hacer este texto.

Por otra parte, como particularidades en el acervo, se identifica una variabilidad en la delimitación temporal de las investigaciones, así como una diversidad temática. Además, se observó la ausencia de ejercicios de contrastación en términos de espacio y tiempo, tanto como la omisión de aspectos de la vida del sujeto-fotógrafo que expliquen la perspectiva proyectada en su trabajo; en la mayoría de los casos, los objetos de las pesquisas, aluden a localidades específicas, limitaciones que circunscriben la interpretación de la realidad y revelan la necesidad de establecer variables multidimensionales para ofrecer interpretaciones integrales y vastas.

\section{Marco teórico: perspectiva teórica}

El posicionamiento teórico de este trabajo parte de la conceptualización de los Estudios Culturales como el ámbito en el cual se escrutan ideas y objetos en constante reformulación, los que otorgan un orden a la realidad de los individuos. Tal consideración proviene de la disertación de Alejandro Grimson y Sergio Caggiano, quienes los definen como una perspectiva epistémica desde la cual analizar la materialización de las actividades humanas y las nuevas miradas que recaen en ellas ${ }^{17}$.

Ambos autores establecen, además, que los Estudios Culturales constituyen un espacio en el que se observa la convergencia de múltiples perspectivas, se examinan

\footnotetext{
${ }^{15}$ Flora Roa Gutiérrez y Alejandra Chaverri Álvarez, Las fotos de mi tata. Mario Roa: Costa Rica (1936-1946) (Cartago: Editorial Tecnológica de Costa Rica, 2017).

${ }^{16}$ Flora Ovares y Margarita Rojas, La ciudad imaginada (San José: Editorial Costa Rica, 2015).

${ }^{17}$ Alejandro Grimson y Sergio Caggiano, «Respuestas a un cuestionario: posiciones y situaciones», en En torno a los Estudios Culturales. Localidades, trayectorias y disputas (Buenos Aires: Editorial Arcis/CLACSO, 2010), 17-30
} 
las relaciones de poder y se atiende el quehacer de los subyugados desde la transdisciplinariedad, dado que sus objetos de estudio conducen a la superación de las barreras disciplinares. De esta manera, su relevancia radica en explicar la elaboración de «un sentido común» y elucidar las relaciones de poder imbricadas en tal proceso ${ }^{18}$.

Como complemento a la visión descrita, y para profundizar su alcance, se acopia la noción de Estudios Culturales de Lawrence Grossberg, quien en contraposición al discurso disyuntivo de una academia moderna, y omitiendo esencialismos, los precisa como un campo donde prima lo conjuntivo; es decir, la consideración de que la realidad está compuesta por la unión de relaciones de diversa naturaleza ${ }^{19}$; por ello, propone la articulación como una práctica de análisis.

La articulación es una propuesta de investigación que exalta el contextualismo y se centra en la producción de la realidad, de los contextos y del poder ${ }^{20}$. Esta parte de la deconstrucción y la reconstrucción como acciones para diseccionar totalidades o unidades, en apariencia armónicas, que esconden los procesos de vinculación que las han forjado y con los cuales se elucida la heterogeneidad de los agentes involucrados que reconstituyen la realidad ${ }^{21}$, de allí su definición, también, como una práctica transformadora ${ }^{22}$.

\section{La identidad: un capital en disputa}

Los Estudios Culturales configuran una esfera epistemológica que revela las disputas por la implantación de un orden; por esta razón, son una importante vertiente en el estudio sobre la instauración de representaciones hegemónicas: práctica articulatoria $^{23}$ ejecutada por individuos quienes, dentro de un sistema relacional, operan sin filiaciones absolutas en campos inestables e integran fuerzas antagónicas enfrentadas para obtener una posición en la cual detentar el poder.

Desde esa perspectiva, se aprecia que la hegemonía no alude a totalidades ni a esencialismos, refiere a una relación política ${ }^{24}$ que expresa equivalencias y diferencias; de este modo, dilucida la naturaleza abierta y mutable de la sociedad. Grossberg lo ha percibido así, por ello ha propuesto la indagación de los distintos medios a través de los cuales el poder circula, se configura y espacializa ${ }^{25}$, con la intención de atender un tópico medular dentro de la temática cultural a la cual está asociado: la identidad.

De acuerdo con este investigador, la identidad es una elaboración social porque para crear una se recurre al señalamiento de la diferencia entre sujetos. Para explicar esta

\footnotetext{
${ }^{18}$ Ibíd., 17-19.

${ }^{19}$ Lawrence Grossberg, «El corazón de los estudios culturales: Contextualidad, construccionismo y complejidad», Tabula Rasa 10 (2009): 13-48, acceso: 01 de junio de 2020, http://www.scielo.org.co/pdf/tara/n10/n10a02.pdf

${ }^{20}$ Ibíd., 29.

${ }^{21}$ Ibíd., 31.

${ }^{22}$ Lawrence Grossberg, «Identidad y estudios culturales, ¿no hay nada más que eso?», en Cuestiones de identidad cultural (Buenos Aires: Amorrortu, 2003), 148-180

${ }^{23}$ Ernesto Laclau y Chantal Mouffe, Hegemonía y estrategia socialista. Hacia una radicalización de la democracia (Madrid: Siglo XXI, 1987). Edición en PDF, 229.

${ }^{24}$ Ibíd., 241.

${ }^{25}$ Lawrence Grossberg, Estudios Culturales. Teoría política y práctica (Valencia: Letra Capital, 2010), edición en PDF.
} 
construcción, emplea la teoría de la otredad, planteamiento que reconoce la existencia del otro y que se determina por «su facultad particular (contextual) de afectar o ser afectado ${ }^{26}$; de esta manera, la identidad se presenta como un constructo relacional, inacabado y siempre dependiente de la reafirmación de lo que no es ${ }^{27}$.

Por las correspondencias que implican, las identidades no son invariables ni fijas; dada su naturaleza política ${ }^{28}$ se definen (y redefinen) al exponerse a las múltiples interacciones que emanan del contexto en el que se encuentran inmersas; situación que lleva al análisis conjunto de las formulaciones identitarias, tanto hegemónicas como contra hegemónicas (subalterna y de resistencia), porque ellas son «mutuamente constitutivas» ${ }^{29}$.

La lectura de esta reciprocidad permite apreciar las estrategias a través de las cuales «los planos de identificación» se producen, articulan e imponen ${ }^{30}$; actos que cita Grossberg al referirse a la asociación entre cultura y poder, ya que son parte de una «maquinaria» que describe a su vez la subjetividad, identidad y agencia que impone un grupo dominante dentro de un conjunto heterogéneo de actuantes que cuentan con distintas posibilidades de ejercer la dominación ${ }^{31}$.

Así, el poder se manifiesta en lo que Cornelius Castoriadis llamó heteronomía ${ }^{32}$, para referirse a la pérdida de la autonomía en el ser humano, quien al ser condicionado por otro, actúa irreflexivamente y en atención a una voluntad ajena: «El sujeto no dice, sino que es dicho por alguien...» ${ }^{33}$, y fomenta, a la vez, la reproducción social de lo instituido, en este caso la cultura, que opera como mecanismo de alienación.

\section{La conceptualización del fotógrafo}

Es importante señalar que la fotografía no es un texto objetivo. Aún si se practicara como un ejercicio experimental, controlado y estructurado, siempre está presente la intuición o la motivación que yace en la sensibilidad del individuo que toma la imagen, aprehensión que se desprende de las relaciones con las cuales establece un sentido a su existencia. Pierre Bourdieu ${ }^{34}$ reflexiona sobre esta situación en el texto La fotografía: un arte intermedio, cuando se refiere a la subjetividad objetivada: aunque la construcción de un sistema de relaciones esté basada en conductas y regularidades mensurables, la vinculación imbrica la experiencia de la significación $^{35}$.

A partir de esta premisa, se concibe al fotógrafo como un sujeto que parte de la experiencia para capturar una imagen, la cual, según su pertenencia a una clase social (o a un colectivo en particular), identifica aquello que es fotografiable según los

\footnotetext{
${ }^{26}$ Ibíd., 159.

${ }^{27}$ Grossberg, Estudios culturales..., 180.

${ }^{28}$ La acepción política refiere a la concepción del individuo como un ser gregario.

${ }^{29}$ Ibíd., 182.

${ }^{30}$ Grossberg, «Identidad y estudios culturales...», 166.

${ }^{31}$ Ibíd., 168.

32 Cornelius Castoriadis, Poder, política, autonomía, acceso: 01 de junio de 2020, https://omegalfa.es/downloadfile.php?file=libros/poder-politica-y-autonomia.pdf, 6 .

33 Cornelius Castoriadis, La institución imaginaria de la sociedad (México: Fábula en Tusquets Editores, 2013), 163.

${ }^{34}$ Pierre Bourdieu, La fotografía: un arte intermedio (México: Editorial Nueva Imagen, 1979).

${ }^{35}$ Ibíd., 18.
} 
cánones que dicta su adscripción ${ }^{36}$. En este sentido, el estudio de la fotografía denota las intenciones explícitas de su autor, pero también connota los intereses implícitos en la exclusión o en el ocultamiento temático; así, se elucida su ubicación dentro de una estructura social ${ }^{37}$.

Conviene agregar que el abordaje de la fotografía asumido en esta reflexión es interpretativo y, por ello, se retomaron las propuestas de Erwin Panofsky ${ }^{38}$, quien concibió la necesidad de contextualizar toda imagen para su valoración para trascender la mera descripción. Según el acto de interpretación, Panofsky definió un método de estudio basado en tres niveles: la pre-descripción iconográfica, el análisis iconográfico y la interpretación iconológica ${ }^{39}$, procedimiento considerado en la sistematización y tratamiento documental de este trabajo.

En el acto de interpretación iconológica incide lo que este autor denominó «Historia de los síntomas culturales o símbolos en general ${ }^{40}$, dimensión que alude a las condiciones históricas que justifican la disposición humana a esgrimir conceptos específicos y en la que, al igual que un artista, el fotógrafo participa; por ello, amerita ser comprendido a partir de su devenir personal para conocer el campo ideológico ${ }^{41}$ al que pertenece, así como su ubicación dentro del campo intelectual; condiciones que lo posicionan como un productor de bienes simbólicos.

Al concatenar los aportes de Bourdieu con los tomados de los otros autores citados en este apartado, se vislumbra que el fotógrafo es una persona con la facultad de incidir en la cosmovisión de varios grupos sociales: no es un ser aislado y su praxis ha estado asociada a la organización y producción de representaciones que lo ubican como un mediador entre «el pueblo y las clases dominantes» que procura preservar los intereses de una hegemonía ${ }^{42}$, razón por la cual debe analizarse su rol dentro de las relaciones de poder.

Las imágenes que realiza un fotógrafo, entonces, son representaciones socio culturales; a través de ellas se devela una coyuntura histórica y, además, se muestra la mirada de quien condiciona y manipula el obturador: por lo general, el hegemón que procura controlar la producción de significado en beneficio propio; razón por la cual su figura se torna relevante de presentar en este apartado, pues su quehacer no es impoluto y, por ello, su conceptualización se debe incorporar dentro de los Estudios Culturales.

\footnotetext{
36 Ibíd., 22.

${ }^{37}$ Ibíd., 25.

${ }^{38}$ Erwin Panofsky, El significado de las artes visuales (Madrid: Alianza Editorial, S.A., 1979), edición en PDF 46.

${ }^{39}$ Ibíd., 60.

${ }^{40}$ Ibíd.

${ }^{41}$ Pierre Bourdieu, Intelectuales, política y poder (Buenos Aires: Eudeba, 2011).

42 Giovanna Giglioli, «Los intelectuales orgánicos en la teoría de Gramsci», Revista Reflexiones 46 (1996): 29-36, acceso: 01 de junio de https://revistas.ucr.ac.cr/index.php/reflexiones/article/view/10907/10283
} 


\section{Marco metodológico: materiales y métodos}

\section{Materiales: el fotógrafo y las imágenes}

Amando Céspedes Marín (1881-1976) fue un distinguido fotógrafo costarricense; sin embargo, se le reconoce también como un pionero en el campo del cine y de la radiodifusión: hizo la primera cinta cinematográfica nacional (1912) y fundó la primera estación radiofónica en el país $(1928)^{43}$. Desde niño se interesó por la comunicación y empezó a visitar el periódico La Prensa Libre, espacio que le acercó a los escritos de autores como José Martí y Benito Pérez Galdós, entre muchos otros que leyó ${ }^{44}$. Migró a Estados Unidos, donde se formó como fotógrafo, de regreso en Costa Rica, laboró como tal y, además, fue colaborador en varios gobiernos por sus inquietudes innovadoras en el área de la difusión escrita y radial.

En el gobierno de Ascensión Esquivel Ibarra fue nombrado representante costarricense para la Exposición Mundial de San Luis, Estados Unidos (evento internacional acaecido en 1904 donde, entre varios efectos, se exponían adelantos tecnológicos); allí, conoció a investigadores disruptivos de la época, tales como Tomás Alva Edison y Santos Dumont, quienes estimularon su espíritu emprendedor. Su visión progresista le reunió con gobernantes liberales afines, quienes durante las primeras décadas del siglo XX procuraron introducir a Costa Rica en la modernidad, primero con Esquivel y luego con Cleto González Víquez. Este último reconoció su liderazgo nacional e internacional en el campo de la comunicación, además le eximió de pagar tributos por servicios de radiodifusión ${ }^{45}$.

En cuanto al material para realizar el análisis, se compiló un acervo compuesto por 20 fotografías en blanco y negro, diez con temas urbanos y diez con tópicos rurales; las primeras se centran en la ciudad de Heredia, en tanto las segundas corresponden a poblados en Guanacaste, Puntarenas, Heredia y Alajuela (tabla 1). Estas se seleccionaron porque muestran asentamientos humanos, revelan distintas dinámicas socioculturales y fueron hechas entre 1905 y 1923, periodo próximo al primer centenario de la Independencia.

Las fuentes consultadas fueron dos: la Pinacoteca Costarricense Electrónica (PINCEL), en el sitio www.artecostarica.cr, de la cual se obtuvieron las imágenes heredianas; mientras que el resto se consiguió en el Sistema Nacional de Bibliotecas (SINABI), a través de su portal https://desarrollo.sinabi.go.cr.

\section{El método: la sistematización}

Se procedió a realizar un estudio de la narrativa de las imágenes bajo los siguientes criterios: tema (¿Qué cuenta la fotografía?), expresión gráfica (¿Cómo lo cuenta?), actores (¿Quiénes participan?) y cualidades (¿Cuáles valores representa la imagen?). De seguido, el escrutinio se sistematizó en dos tablas (tablas 2 y 3 ), en las cuales las

\footnotetext{
43 Norma Loaiza, «Amando Céspedes Marín: hombre-cumbre cuya obra es toda una brillante biografía», La Nación, 30 de octubre de 1966, acceso: 01 de junio de 2020, http://repositorio.sibdi.ucr.ac.cr:8080/jspui/handle/123456789/6787

${ }^{44}$ Ibid.

${ }^{45}$ Ibid. 
fotos aparecen numeradas (según la tabla 1) y se adjuntan las observaciones para luego cotejarlas y puntualizar los hallazgos.

Tabla 1 Fotografías seleccionadas

\begin{tabular}{|c|c|}
\hline $\begin{array}{l}\text { Fotografías rurales } \\
\text { (lugares varios, 1923) }\end{array}$ & $\begin{array}{l}\text { Fotografías urbanas } \\
\text { (Heredia, 1905-1921) }\end{array}$ \\
\hline $\begin{array}{l}\text { 1. Iglesia de Cañas (Guanacaste) } \\
\text { 2. Puerto de Río Bebedero } \\
\text { (Guanacaste) } \\
\text { 3. Iglesia de Puntarenas } \\
\text { (Puntarenas) } \\
\text { 4. Iglesia de Térraba (Puntarenas) } \\
\text { 5. Raudal del Berva, Río Grande de } \\
\text { Térraba (Puntarenas) } \\
\text { 6. Boruca (Puntarenas) } \\
\text { 7. Térraba (Puntarenas) } \\
\text { 8. Resguardo de Los Chiles } \\
\text { (Alajuela) } \\
\text { 9. Raudal en Río San Carlos } \\
\text { (Alajuela) } \\
\text { 10. Playuela de Río Frío (Sarapiquí, } \\
\text { Heredia) }\end{array}$ & $\begin{array}{l}\text { 11. Calle del cementerio } \\
\text { 12. Costado oeste de la Iglesia } \\
\text { parroquial de la Inmaculada } \\
\text { Concepción } \\
\text { 13. Iglesia parroquial de la Inmaculada } \\
\text { Concepción } \\
\text { 14. El Fortín } \\
\text { 15. Escuela Braulio Morales } \\
\text { 16. Estación del ferrocarril } \\
\text { 17. Parque central de Heredia } \\
\text { 18. Penitenciaría en Heredia } \\
\text { 19. Iglesia del Carmen } \\
\text { 20. Plaza de la Puebla, Heredia }\end{array}$ \\
\hline
\end{tabular}

Fuente: http://www.artecostarica.cr/artistas/cespedes-amando y https://desarrollo.sinabi.go.cr/biblioteca\%20digital/fotos/Folografias\%20de\%20A mando\%20Cespedes.aspx\#.XeLV8ehKjIV

Tabla 2 Tabulación de observaciones sobre fotografías rurales

\begin{tabular}{|c|c|c|c|c|}
\hline Foto & Tema & Expresión gráfica & Actores & Cualidades \\
\hline 1 & $\begin{array}{l}\text { Sociabilidad } \\
\text { en el espacio } \\
\text { público (en } \\
\text { torno a la } \\
\text { iglesia de } \\
\text { Cañas). }\end{array}$ & $\begin{array}{l}\text { Colocación de la iglesia en un } \\
\text { plano de fondo, vegetación } \\
\text { como albergue de reunión de } \\
\text { contertulios quienes están en } \\
\text { el centro de la imagen. } \\
\text { - Infraestructura urbana } \\
\text { incipiente (trazo de calles y } \\
\text { aceras, ausencia de alumbrado } \\
\text { y mobiliario). } \\
\text { Personas anónimas (no son } \\
\text { reconocibles por la escala). }\end{array}$ & $\begin{array}{l}\text { Hombres bien } \\
\text { ataviados } \\
\text { (sombrero y } \\
\text { saco), usuarios } \\
\text { del espacio } \\
\text { público. }\end{array}$ & Camaradería \\
\hline 2 & $\begin{array}{l}\text { Jornada } \\
\text { laboral en } \\
\text { puerto del } \\
\text { Río } \\
\text { Bebedero. }\end{array}$ & $\begin{array}{l}\text { Ubicación en primer plano de } \\
\text { trabajadores locales en patio } \\
\text { con troncos de madera que } \\
\text { sirven para construir botes. } \\
\text { Destaca en el centro de la } \\
\text { imagen un trabajador de pie } \\
\text { sobre un tronco que es parte de } \\
\text { un lote maderero. }\end{array}$ & $\begin{array}{l}\text { El grupo de } \\
\text { trabajadores } \\
\text { agrícolas y el } \\
\text { lote de troncos } \\
\text { para hacer los } \\
\text { botes. }\end{array}$ & Laboriosidad \\
\hline
\end{tabular}




\begin{tabular}{|c|c|c|c|c|}
\hline & & $\begin{array}{l}\text { - Ausencia de infraestructura } \\
\text { vial y de servicios (alumbrado, } \\
\text { agua, mobiliario). }\end{array}$ & & \\
\hline 3 & $\begin{array}{l}\text { El nodo } \\
\text { central de } \\
\text { una } \\
\text { población } \\
\text { (Puntarenas). }\end{array}$ & $\begin{array}{l}\text { Preeminencia de la iglesia } \\
\text { católica en un espacio público } \\
\text { conformado por sus jardines, } \\
\text { aceras y plaza. } \\
\text { - Presencia significativa de } \\
\text { vegetación en un sitio que } \\
\text { tiene infraestructura básica } \\
\text { (alumbrado, calles y aceras). }\end{array}$ & $\begin{array}{l}\text { El templo y } \\
\text { usuarios de } \\
\text { espacio } \\
\text { público. }\end{array}$ & $\begin{array}{l}\text { Orden } \\
\text { (jerarquía) }\end{array}$ \\
\hline 4 & $\begin{array}{l}\text { La iglesia } \\
\text { como parte } \\
\text { de un } \\
\text { entorno } \\
\text { agreste. }\end{array}$ & $\begin{array}{l}\text { - Predominio del entorno } \\
\text { natural y la iglesia como parte } \\
\text { de la estampa. } \\
\text { - Presencia de la vegetación en } \\
\text { planos representativos. } \\
\text { - Ausencia de infraestructura y } \\
\text { seres humanos. }\end{array}$ & $\begin{array}{l}\text { La naturaleza } \\
\text { envolvente. }\end{array}$ & Realismo \\
\hline 5 & $\begin{array}{l}\text { Boteros } \\
\text { arriban a } \\
\text { ribera del río } \\
\text { Térraba. }\end{array}$ & $\begin{array}{l}\text { El grupo de boteros y } \\
\text { pasajeros ocupan el espacio } \\
\text { central de la imagen. } \\
\text { - Presencia en primer plano de } \\
\text { sustrato pedregoso (ribera } \\
\text { accidentada por el curso del } \\
\text { río) } \\
\text { - Hombres anónimos (no se } \\
\text { aprecian sus caras) y obreros } \\
\text { (su ropaje lo delata). }\end{array}$ & $\begin{array}{l}\text { El río Térraba } \\
\text { impetuoso. }\end{array}$ & Valentía \\
\hline 6 & $\begin{array}{l}\text { Boruca } \\
\text { como } \\
\text { asentamiento } \\
\text { montañoso. }\end{array}$ & $\begin{array}{l}\text { Distribución de predios de } \\
\text { Boruca en una colina: } \\
\text { prevalece el promontorio } \\
\text { como elemento que dirime la } \\
\text { colocación de inmuebles. } \\
\text { - La iglesia se distingue por su } \\
\text { ubicación en la pendiente, su } \\
\text { color y su disposición en la } \\
\text { imagen. } \\
\text { - Presencia de bestias de } \\
\text { trabajo, peones, casas de } \\
\text { palma y cercas de madera. } \\
\text { Ausencia de infraestructura } \\
\text { vial y servicios. }\end{array}$ & $\begin{array}{l}\text { Boruca como } \\
\text { pueblo rural. }\end{array}$ & $\begin{array}{l}\text { Orden } \\
\text { (jerarquía) }\end{array}$ \\
\hline 7 & $\begin{array}{l}\text { Térraba } \\
\text { como } \\
\text { asentamiento } \\
\text { agreste. }\end{array}$ & $\begin{array}{l}\text { Organización horizontal que } \\
\text { destaca por su ubicación } \\
\text { central en la composición, una } \\
\text { fila de personas (se asumen } \\
\text { como vecinos). } \\
\text { - Viviendas dispersas hechas de } \\
\text { palma son parte de un entorno } \\
\text { en el cual prima la naturaleza, } \\
\text { elementos que son escenario } \\
\text { de los sujetos fotografiados. }\end{array}$ & $\begin{array}{l}\text { Las personas } \\
\text { en el centro de } \\
\text { la imagen y el } \\
\text { entorno como } \\
\text { encuadre. }\end{array}$ & $\begin{array}{l}\text { Orden } \\
\text { (jerarquía) }\end{array}$ \\
\hline
\end{tabular}




\begin{tabular}{|c|c|c|c|c|}
\hline 8 & $\begin{array}{l}\text { La frontera } \\
\text { norte como } \\
\text { ficción } \\
\text { territorial. }\end{array}$ & $\begin{array}{l}\text { - Composición lineal en } \\
\text { perspectiva descentralizada } \\
\text { que permite apreciar un borde } \\
\text { virtual (establecido por dos } \\
\text { edificaciones), pero que deja } \\
\text { entrever vacíos (porosidades) } \\
\text { en las que se entremezclan los } \\
\text { entornos jurisdiccionalmente } \\
\text { separados. } \\
\text { Edificaciones en palma, } \\
\text { material que les permite } \\
\text { mimetizarse con el entorno. }\end{array}$ & $\begin{array}{l}\text { La linealidad } \\
\text { de una frontera } \\
\text { intangible. Las } \\
\text { personas como } \\
\text { parte del } \\
\text { escenario. }\end{array}$ & $\begin{array}{l}\text { Orden } \\
\text { (exclusión) }\end{array}$ \\
\hline 9 & $\begin{array}{l}\text { El río San } \\
\text { Carlos como } \\
\text { generador de } \\
\text { vida (natural } \\
\text { y social). }\end{array}$ & $\begin{array}{l}\text { - Río ocupa el espacio principal } \\
\text { de la imagen: ocupa gran área } \\
\text { de la toma, la vegetación está } \\
\text { supeditada a él en la } \\
\text { composición, mientras los } \\
\text { boteros (de pie en el bote) dan } \\
\text { una escala del tamaño río. } \\
\text { - Ausencia de la impronta } \\
\text { humana (salvo por los boteros } \\
\text { y sus naves). }\end{array}$ & $\begin{array}{l}\text { El río } \\
\text { magnánimo, } \\
\text { los boteros } \\
\text { nimios ante la } \\
\text { naturaleza. }\end{array}$ & $\begin{array}{l}\text { Valentía y } \\
\text { respeto }\end{array}$ \\
\hline 10 & $\begin{array}{l}\text { Despoblado } \\
\text { humano: el } \\
\text { hombre, la } \\
\text { bestia y el } \\
\text { rancho. }\end{array}$ & $\begin{array}{l}\text { Destaca por el claro-oscuro, la } \\
\text { presencia en solitario del } \\
\text { hombre frente al río. En la } \\
\text { imagen se percibe un entorno } \\
\text { socialmente yermo: estéril en } \\
\text { cuanto a la no-observación de } \\
\text { otros vestigios humanos. } \\
\text { - La playuela se presenta como } \\
\text { la vinculación del ser humano } \\
\text { con la naturaleza. }\end{array}$ & $\begin{array}{l}\text { El hombre y la } \\
\text { naturaleza. }\end{array}$ & Introspección \\
\hline
\end{tabular}

Fuente: Elaboración propia con base en:

https://desarrollo.sinabi.go.cr/biblioteca\%20digital/fotos/Folografias\%20de\%20A mando\%20Cespedes.aspx\#.XeLV8ehKjIV

Tabla 3 Tabulación de observaciones sobre fotografías urbanas

\begin{tabular}{|c|c|c|c|c|}
\hline Foto & Tema & Expresión gráfica & Actores & Cualidades \\
\hline 11 & $\begin{array}{l}\text { La impronta } \\
\text { religiosa en } \\
\text { vía pública } \\
\text { mediante la } \\
\text { celebración } \\
\text { fuera del } \\
\text { templo. }\end{array}$ & $\begin{array}{l}\text { Destaca por su ubicación } \\
\text { central de la imagen, los } \\
\text { símbolos religiosos: un } \\
\text { cordero, el santísimo } \\
\text { sacramento y el saludo en } \\
\text { latín. En el mismo plano se } \\
\text { observan feligreses (niños y } \\
\text { adultos) congregados en la } \\
\text { calle. } \\
\text { La perspectiva es ilustrada por } \\
\text { el trazo de la calle, las aceras, } \\
\text { los postes y sus } \\
\text { correspondientes cables, } \\
\text { elementos que muestran el } \\
\text { progreso en cuanto a } \\
\text { infraestructura de la } \\
\text { comunidad herediana. }\end{array}$ & $\begin{array}{l}\text { Los símbolos } \\
\text { religiosos de la } \\
\text { fe católica y } \\
\text { los acólitos } \\
\text { apostados en } \\
\text { la vía pública. }\end{array}$ & $\begin{array}{l}\text { Devoción y } \\
\text { orden }\end{array}$ \\
\hline
\end{tabular}




\begin{tabular}{|c|c|c|c|c|}
\hline 12 & $\begin{array}{l}\text { El ornato de } \\
\text { espacios } \\
\text { urbanos } \\
\text { públicos } \\
\text { centrales. }\end{array}$ & $\begin{array}{l}\text { El trazo urbano (la calle, los } \\
\text { postes del alumbrado, la } \\
\text { acera y sus losetas de piedra, } \\
\text { las bancas de la verja y la } \\
\text { verja misma) es parte de la } \\
\text { composición en la cual } \\
\text { resalta la casa del } \\
\text { expresidente Alfredo } \\
\text { González Flores al final de la } \\
\text { fuga de la perspectiva. } \\
\text { Los sujetos que aparecen son } \\
\text { parte de la composición, al } \\
\text { igual que las montañas al } \\
\text { fondo. }\end{array}$ & $\begin{array}{l}\text { La ciudad } \\
\text { ocupa el lugar } \\
\text { central y en } \\
\text { ella se aprecia } \\
\text { su desarrollo } \\
\text { en cuanto a } \\
\text { infraestructura. }\end{array}$ & Orden e higiene \\
\hline 13 & $\begin{array}{l}\text { La presencia } \\
\text { de la Iglesia } \\
\text { a través del } \\
\text { templo } \\
\text { parroquial } \\
\text { de Heredia. }\end{array}$ & $\begin{array}{l}\text { El templo parroquial } \\
\text { sobresale por su posición, } \\
\text { escala y volumetría, a pesar } \\
\text { de estar en un plano de } \\
\text { fondo. } \\
\text { Diferentes personas figuran } \\
\text { como usuarios del espacio } \\
\text { público (en actividades } \\
\text { diferentes) y pueden ser } \\
\text { dimensionadas mediante los } \\
\text { postes de luz. La vegetación } \\
\text { está relegada a espacios } \\
\text { determinados (parque y } \\
\text { jardines de la iglesia). }\end{array}$ & $\begin{array}{l}\text { El templo } \\
\text { como cuerpo } \\
\text { monolítico, las } \\
\text { personas y el } \\
\text { mobiliario } \\
\text { urbano como } \\
\text { piezas de la } \\
\text { ciudad. }\end{array}$ & $\begin{array}{l}\text { Fortaleza y } \\
\text { robustez }\end{array}$ \\
\hline 14 & $\begin{array}{l}\text { El parque de } \\
\text { juegos como } \\
\text { parte de un } \\
\text { centro } \\
\text { cívico. }\end{array}$ & $\begin{array}{l}\text { Cruce de dos perspectivas } \\
\text { que resaltan, en el centro de } \\
\text { la imagen, la entrada a un } \\
\text { parque infantil. Sobresalen } \\
\text { en la composición, la } \\
\text { infraestructura urbana y el } \\
\text { fortín al fondo (en distintos } \\
\text { planos). } \\
\text { Un parque infantil luce como } \\
\text { espacio contenido y se } \\
\text { aprecian mujeres en él } \\
\text { (feminización del sitio), } \\
\text { ausencia de vegetación } \\
\text { espontánea y de otros } \\
\text { elementos que refieran a la } \\
\text { naturaleza. }\end{array}$ & $\begin{array}{l}\text { La } \\
\text { infraestructura } \\
\text { urbana en } \\
\text { múltiples } \\
\text { planos y la } \\
\text { personas como } \\
\text { parte de ella. }\end{array}$ & Orden y control \\
\hline 15 & $\begin{array}{l}\text { La presencia } \\
\text { de la } \\
\text { escuela } \\
\text { como parte } \\
\text { del sistema } \\
\text { institucional } \\
\text { urbano. }\end{array}$ & $\begin{array}{l}\text { Preminencia de la fachada } \\
\text { del inmueble escolar en el } \\
\text { plano de fuga que remata } \\
\text { con la iglesia parroquial, } \\
\text { acorde con el trazo urbano. } \\
\text { Farola que expresa el } \\
\text { avance en cuanto a } \\
\text { infraestructura. }\end{array}$ & $\begin{array}{l}\text { La escuela, el } \\
\text { trazo urbano y } \\
\text { la persona } \\
\text { como } \\
\text { «modulor». }\end{array}$ & $\begin{array}{l}\text { Orden y } \\
\text { adoctrinamiento }\end{array}$ \\
\hline
\end{tabular}




\begin{tabular}{|c|c|c|c|c|}
\hline & & $\begin{array}{l}\text { Presencia de una persona, } \\
\text { elemento que funciona para } \\
\text { dar escala humana a las } \\
\text { edificaciones y que rompe } \\
\text { con la presencia de la } \\
\text { racionalidad de lo } \\
\text { construido artificialmente. }\end{array}$ & & \\
\hline 16 & $\begin{array}{l}\text { El } \\
\text { ferrocarril } \\
\text { es la clave } \\
\text { del } \\
\text { crecimiento } \\
\text { económico. }\end{array}$ & $\begin{array}{l}\text { Sobresale una estructura } \\
\text { complementaria de la } \\
\text { estación en el plano central } \\
\text { seguida de sus instalaciones. } \\
\text { Le complementa el espacio } \\
\text { de circulación ferroviario, un } \\
\text { vagón y el sistema de } \\
\text { alumbrado. } \\
\text { - Ausencia del individuo como } \\
\text { actor principal, su función es } \\
\text { dar escala a los elementos de } \\
\text { la composición (la persona se } \\
\text { funde con el resto de los } \\
\text { elementos). }\end{array}$ & $\begin{array}{l}\text { El ferrocarril } \\
\text { como } \\
\text { institución del } \\
\text { progreso. }\end{array}$ & Acometividad \\
\hline 17 & $\begin{array}{l}\text { Los jardines } \\
\text { públicos son } \\
\text { naturaleza } \\
\text { regulada. }\end{array}$ & $\begin{array}{l}\text { - El quiosco es figura relevante } \\
\text { por su tamaño y ubicación. } \\
\text { Está rodeado por árboles y } \\
\text { faroles que guardan } \\
\text { similitudes formales, semejan } \\
\text { un bosque. } \\
\text { - El quiosco, las aceras y } \\
\text { bancas insinúan la presencia } \\
\text { de peatones, sin embargo, } \\
\text { ellos están ausentes de la } \\
\text { imagen. } \\
\text { La naturaleza está dispuesta } \\
\text { artificialmente: el césped está } \\
\text { recortado, no hay arbustos } \\
\text { espontáneos y los árboles } \\
\text { están dispuestos según un } \\
\text { orden urbano. }\end{array}$ & $\begin{array}{l}\text { El quiosco es } \\
\text { el elemento } \\
\text { central y el } \\
\text { humano por } \\
\text { omisión. }\end{array}$ & Orden y control \\
\hline 18 & $\begin{array}{l}\text { La presencia } \\
\text { de la } \\
\text { autoridad } \\
\text { judicial } \\
\text { como parte } \\
\text { del sistema } \\
\text { institucional } \\
\text { urbano. }\end{array}$ & $\begin{array}{l}\text { Preminencia de la fachada } \\
\text { del inmueble judicial en el } \\
\text { plano de fuga que se pierde } \\
\text { en el horizonte (donde yacen } \\
\text { las montañas heredianas). } \\
\text { - Trazo urbano evidente, pero } \\
\text { se observa menor calidad en } \\
\text { la infraestructura (calle de } \\
\text { piedra, postes más } \\
\text { distanciados y aceras } \\
\text { estrechas). } \\
\text { La persona como elemento } \\
\text { de escala del inmueble. }\end{array}$ & $\begin{array}{l}\text { La } \\
\text { penitenciaria, } \\
\text { el trazo urbano } \\
\text { y la persona } \\
\text { como } \\
\text { «modulor». }\end{array}$ & $\begin{array}{l}\text { Orden y } \\
\text { justicia }\end{array}$ \\
\hline
\end{tabular}




\begin{tabular}{|c|c|c|c|c|}
\hline 19 & $\begin{array}{l}\text { La } \\
\text { procesión } \\
\text { como } \\
\text { apropiación } \\
\text { del espacio } \\
\text { público } \\
\text { urbano y la } \\
\text { Iglesia } \\
\text { como } \\
\text { institución } \\
\text { hegemónica. }\end{array}$ & $\begin{array}{l}\text { - La muchedumbre y templo } \\
\text { comparten simétricamente la } \\
\text { superficie de la imagen, de } \\
\text { allí que ambos son elementos } \\
\text { preponderantes en ella. } \\
\text { - Las personas lucen como una } \\
\text { «mancha» homogénea, no se } \\
\text { distinguen figuras } \\
\text { particulares ni jerarquías; en } \\
\text { conjunto forman parte de un } \\
\text { cortejo que representa a la } \\
\text { feligresía que instituye a la } \\
\text { iglesia como institución. }\end{array}$ & $\begin{array}{l}\text { El templo y la } \\
\text { feligresía. }\end{array}$ & $\begin{array}{l}\text { Devoción y } \\
\text { liderazgo }\end{array}$ \\
\hline 20 & $\begin{array}{l}\text { Estampa de } \\
\text { la periferia } \\
\text { urbana de } \\
\text { Heredia. }\end{array}$ & $\begin{array}{l}\text { Presencia en primer plano de } \\
\text { una calle de lastre y de un } \\
\text { niño corriendo en ella; } \\
\text { posterior a la vía, hay tres } \\
\text { árboles semejantes, que son } \\
\text { el contrapeso de un espacio } \\
\text { vacío en el que se observa la } \\
\text { ciudad de Heredia. En el } \\
\text { perfil de esta sobresalen los } \\
\text { templos de la Iglesia del } \\
\text { Carmen y de la Inmaculada } \\
\text { Concepción. } \\
\text { Ausencia de infraestructura } \\
\text { urbana, presencia de un trazo } \\
\text { vial, preminencia de zonas } \\
\text { verdes (fincas) en el paisaje, } \\
\text { que se anteponen a las } \\
\text { montañas en un plano } \\
\text { ulterior. }\end{array}$ & $\begin{array}{l}\text { La ruralidad } \\
\text { de la periferia } \\
\text { urbana, el niño } \\
\text { como } \\
\text { elemento } \\
\text { humanizante. }\end{array}$ & $\begin{array}{l}\text { Disposición } \\
\text { (jerarquía) }\end{array}$ \\
\hline
\end{tabular}

Fuente: Elaboración propia con base en

http://www.artecostarica.cr/artistas/cespedes-amando

\section{Resultados, análisis y discusión}

Entre los hallazgos más significativos está el tipo de tópicos recurrentes, tanto en las imágenes rurales como en las urbanas. En las primeras prevalecen temáticas asociadas con componentes del hábitat, tales como los ríos navegables y el entorno agreste (figura 1), incluso en objetos de manufactura humana: las casas de palma, las iglesias de madera y los botes modelados a partir de troncos de árboles; los individuos aparecen como personajes secundarios, forman parte del paisaje y, en algunos casos, su pose realza la escala y la magnitud de la fuerza de elementos naturales. 


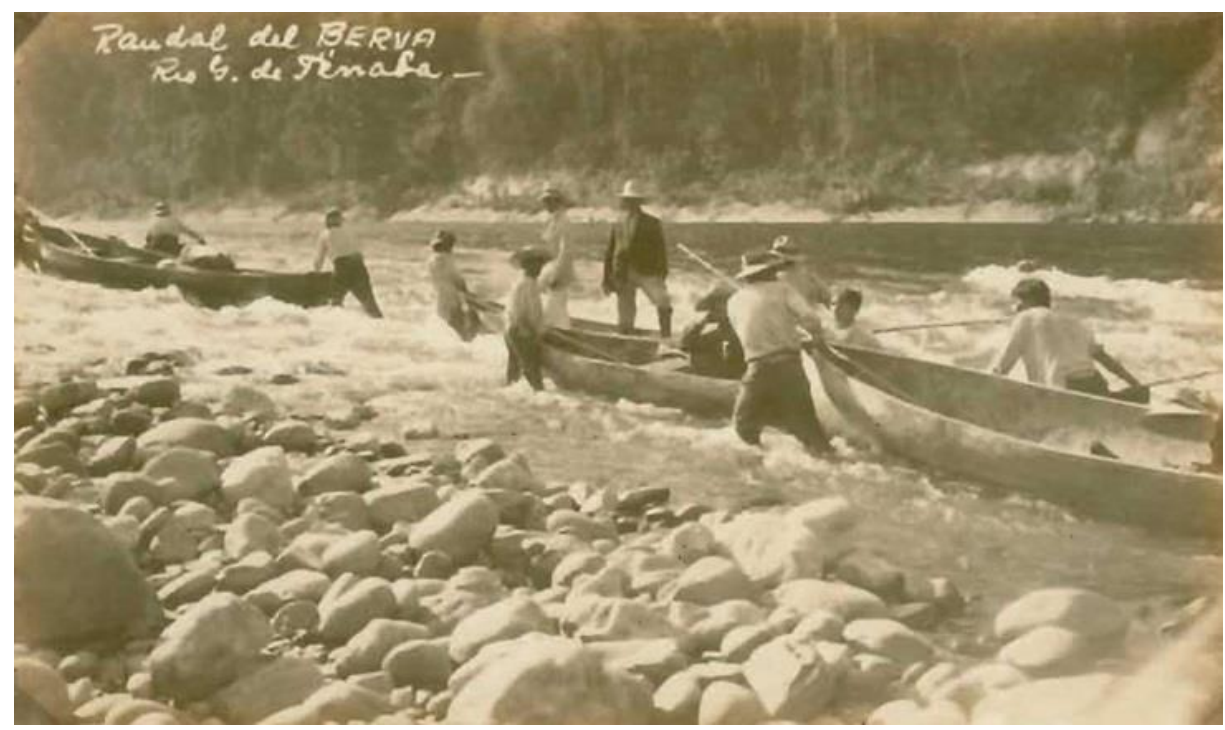

Figura 1 Río Grande de Térraba. (Amando Céspedes Marín. 1921. Sinabi. Tomada de:https://www.sinabi.go.cr/biblioteca\%20digital/fotos/amando\%20cespedes/visita $\% 20 a \% 20$ buenos\%20aires\%20de\%20terraba/k-

Raudal\%20del\%20Berva.jpg? $w=1024)$

Otro descubrimiento radica en la coincidencia de los valores: predomina el orden, especialmente en las imágenes que refieren a asentamientos. Empero, este orden no está asociado a una grilla o plano predefinido, utiliza las bondades del entorno, tales como explanadas (algunas incrustadas en pendientes) o emplazamientos junto a rutas de tránsito fluvial o terrestre, como puntos organizadores para dirimir la disposición de viviendas, iglesias y patios; vale mencionar que en estas imágenes se observa la completa ausencia de infraestructura urbana cuya lógica de construcción suele determinar el ordenamiento territorial (figura 2).

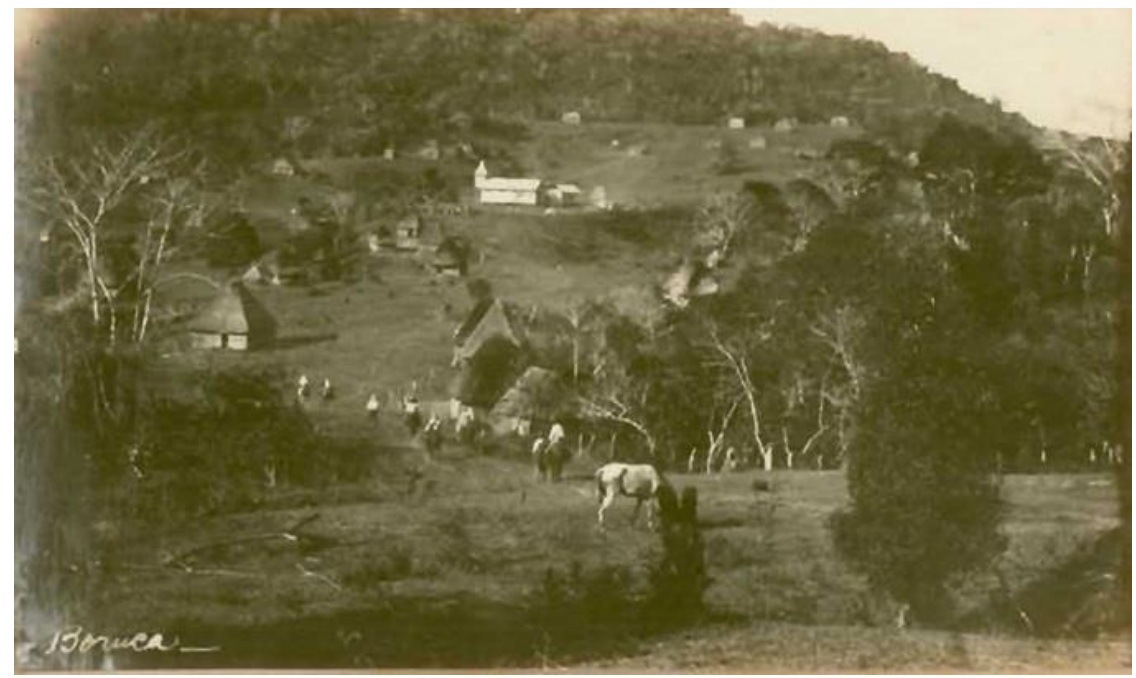

Figura 2 Asentamiento de Boruca. (Amando Céspedes Marín. 1921. Sinabi.

Tomada de:

https://www.sinabi.go.cr/biblioteca\%20digital/fotos/amando\%20cespedes/visita\%2 Oa\%20buenos\%20aires\%20de\%20terraba/n-Boruca.jpg?w=1024) 
En el lote de fotografías urbanas, las revelaciones yacen en los mismos aspectos, los temas y los valores. El tema que predomina es la ciudad, en las imágenes se detalló que el trazo vial sirve como un componente que ordena la composición fotográfica (figura 3). En la urbe aparecen distintas edificaciones que hablan del progreso logrado en distintos ámbitos: la escuela, la iglesia, el ferrocarril, el parque infantil, la comandancia y el parque central; las personas están para dimensionar el tamaño de los inmuebles y para humanizar los pasajes (figura 4).

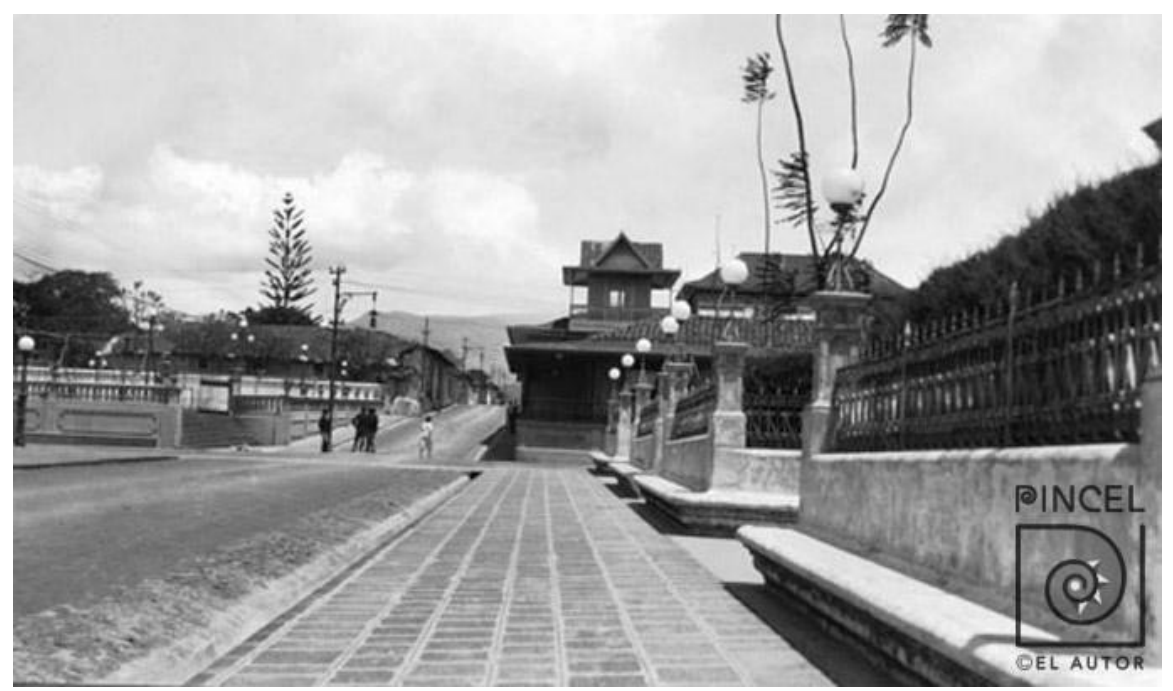

Figura 3 Calzada y mobiliario urbano en el costado oeste de la iglesia de la Parroquia de la Inmaculada Concepción, Heredia. (Amando Céspedes Marín. 1921. Sinabi. Tomada de:

http://www.artecostarica.cr/sites/default/files/Obras/images/cespedes_amando/127 63_OACe_003.jpg)

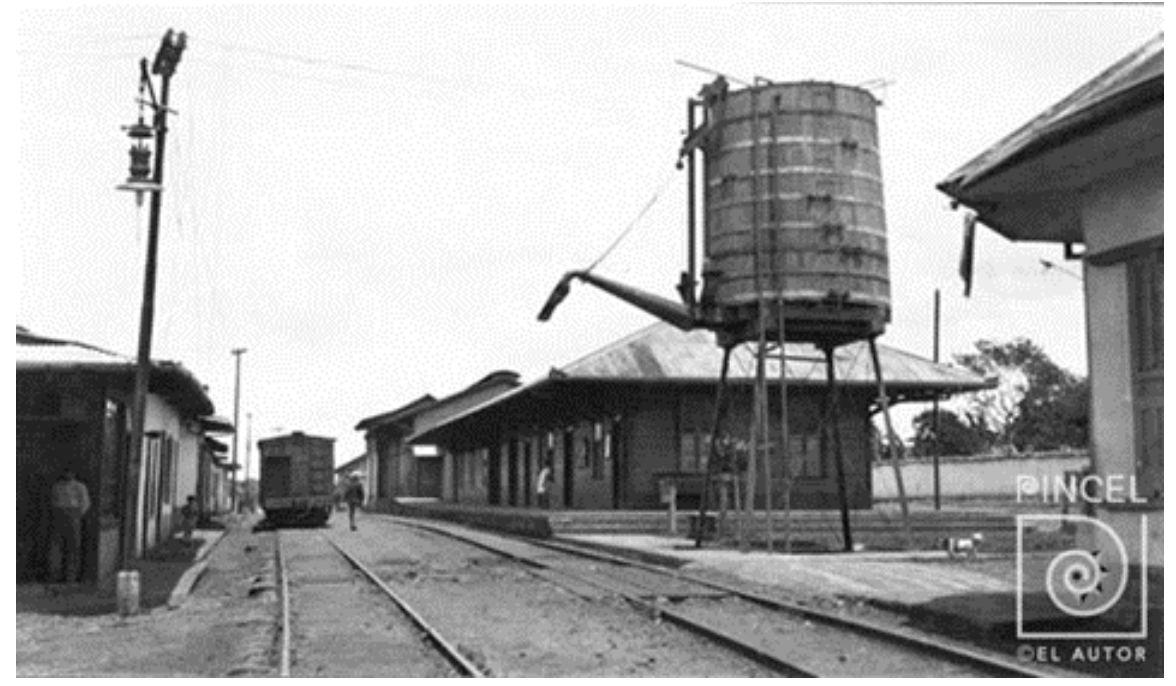

Figura 4 Imagen de la Estación del Tren, Heredia (Amando Céspedes Marín. 1921. Sinabi. Tomada de:

http://www.artecostarica.cr/sites/default/files/Obras/images/cespedes_amando/127 66_OACe_006.jpg) 
Sobre los valores observados prima el orden: las fotos exhiben una estructuración urbana que luce impecable, limpia, sin visos de irregularidades ni transgresión alguna; del mismo modo, se refleja en edificaciones de un gran poder simbólico, tales como la comandancia (orden judicial), la escuela (orden ideológico) y los parques públicos (orden vigilante). Los actos litúrgicos también muestran esa pauta: las personas están dispuestas junto a la calle o dentro de ella, como parte del evento, y son respetuosas de su guion litúrgico.

Para continuar con el análisis y la discusión, es necesario retomar la idea que orientó este escrito: ¿Cuál es la imagen de Costa Rica tras un siglo de vida independiente? Con base en lo apreciado, se afirma que Amando Céspedes Marín creó una imagen en cuya concepción de la identidad costarricense se pondera mejor el mundo urbano que el rural, pues en ese se proyecta una nación consolidada.

La coyuntura económica de la época produjo una bonanza sustentada en la actividad cafetalera de exportación, la cual permitió la inversión en servicios públicos, infraestructura urbana y edilicia; de esta manera, el Estado pudo controlar los espacios de transmisión ideológica mediante la alocución de mensajes que no necesariamente fueron orales: la grandilocuencia de las fachadas de inmuebles públicos, que emularon importantes edificios en Europa, comunicaron que Costa Rica había logrado insertarse con éxito como una república independiente en el comercio internacional, así como beneficiarse de su nueva vinculación con antiguos estados colonizadores. Céspedes Marín, como comunicador, contribuyó con este cometido, por ello coloca a un sujeto en solitario frente a la comisaría o la escuela para expresar su monumentalidad y a la vez expone una nueva transculturación que se manifiesta en la apropiación de un lenguaje arquitectónico foráneo, el cual tornó a las instituciones como polisémicas.

Por otra parte, la necesidad de proyectar una Costa Rica sólida y soberana, obedece al interés de un grupo hegemónico interesado en dejar atrás las irregularidades que rodearon las elecciones presidenciales del inicio de siglo XX; además pretendió desterrar la dictadura como posibilidad de gobierno. Dicho grupo, compuesto por intelectuales con injerencia política y que se denominó «Generación del Olimpo», empleó distintos mecanismos ideológicos para concentrar el poder, entre ellos: la educación, la iglesia, el orden jurídico y la opinión pública ${ }^{46}$; con la arquitectura, lograron materializar los tres primeros aspectos; con la fotografía el cuarto.

Ahora bien ¿Cuál fue el rol de las imágenes rurales en la construcción identitaria propuesta por Amando Céspedes Marín? Antes de responder esta interrogante, es importante indicar que, según los investigadores Iván Molina y Steven Palmer, contrario a la forma de resolver los conflictos en el Valle Central costarricense, a través de la mediación de una normativa jurídica, en las zonas rurales, los indígenas y los campesinos pobres lucharon violentamente por preservar sus tierras, entre los años 1880 y $1930^{47}$. Tal circunstancia muestra a una Costa Rica virulenta, contrapuesta al discurso civilizatorio de una hegemonía urbana.

La gira pastoral emprendida por Céspedes Marín permitió aproximarse a ese «otro» sujeto rural y, para borrar su imagen bárbara y de resistencia, elaboró paisajes donde se asoma la presencia divina (se ve en los templos que son parte de la estampa) en

46 Orlando Mora Salazar, El apogeo de la república liberal en Costa Rica: 1870-1914 (San José: Editorial Universidad de Costa Rica, 2003).

${ }^{47}$ Iván Molina y Steven Palmer, The history of Costa Rica: brief, up to date and illustrated (San José: Editorial Universidad de Costa Rica. 2007). 
poblados calmos cuyos entornos habían sido poco intervenidos por el ser humano y construye, a la vez, la representación de un sujeto campestre que trabaja y se enfrenta a la naturaleza para someterla (en el caso de los boteros, eran los encargados de trasegar las mercancías en esas zonas).

Los figurantes en las fotos seleccionadas son anónimos, aparecen en grupos, a lo lejos o de espalda; lucen iguales y se dificulta distinguir sus rasgos, acto con el cual logra homologarlos e instaurar una identidad única, pues ellos, quienes han estado al margen del control político, deben ser mostrados subalternos ${ }^{48}$; es decir, como seres humanos supeditados a las disposiciones de camarillas ligadas al poder económico, representado en el mercado capitalista.

Para sintetizar lo expuesto hasta ahora, se asevera que Amando Céspedes Marín proyectó una imagen de la Costa Rica centenaria como una nación progresista y consolidada políticamente, gracias a la robustez de una estructura institucional. Es probable que su afán por mostrar este espíritu civilizatorio fuera resultado de su cercanía con miembros de «El Olimpo» y de la importancia que le otorgó a los avances tecnológicos de la época, algunos de los cuales pudo explorar debido a sus inquietudes intelectuales y desempeño profesional.

Sin embargo, también en la omisión, en lo que no dijo, proyectó una imagen de la nación. La ausencia generalizada de la mujer en el ámbito público, de ritos propios de las poblaciones indígenas visitadas, así como de un registro de las condiciones de acceso a las comunidades rurales, niegan la existencia de grupos socialmente vulnerados dentro de una identidad legitimada que aún subsiste: cien años después, las brechas entre las zonas rurales y las urbanas no han desaparecido y, en ellas, distintas formas de segregación se han perpetuado.

Las imágenes analizadas son el testimonio de un intelectual orgánico, quien a través de la creación de imágenes mostró una parte de la realidad sociocultural costarricense y, de ellas, extrajo (según su subjetividad) valores que ancló en el imaginario nacional. Así, su labor incidió en la opinión pública y ha instaurado una identidad basada en un orden que se manifiesta en el apego a la norma institucional, al canon social o al precepto religioso, lo cual se ha eternizado sin provocar mayor cuestionamiento alguno.

Desde esta perspectiva, los Estudios Culturales, asociados a un pensamiento crítico, son el campo apropiado para promover la reflexión y la discusión sobre estas prácticas con urgencia: se vive una época en la cual prima la inmediatez y, por ello, se recurre al impacto que genera lo visual, de allí que se torne imperativo el descubrir y desmantelar los discursos que yacen en las imágenes, pues estas siguen siendo mecanismos óptimos para ejercer un control y preservar relaciones de poder en la cotidianidad.

\footnotetext{
48 «Subalternidad», Instituciones de Investigaciones Sociales (UNAM), acceso: 01 de junio de 2020, http://conceptos.sociales.unam.mx/conceptos_final/497trabajo.pdf 


\section{Formato de citación según APA}

Otárola-Guevara, M. (2020). Amando Céspedes Marín: el intelectual tras el lente y el hacedor de identidades en el papel. Revista Espiga, 20 (40), páginas 1-24.

\section{Formato de citación según Chicago-Deusto}

Otárola-Guevara, Marcela (2020). «Amando Céspedes Marín: el intelectual tras el lente y el hacedor de identidades en el papel». Revista Espiga 20, n. ${ }^{\circ} 40$ (juliodiciembre, 2020): páginas 1-24.

\section{Fuentes consultadas}

Bourdieu, Pierre, ed. La fotografía: un arte intermedio. México: Editorial Nueva Imagen, 1979.

Bourdieu, Pierre. Intelectuales, política y poder. Buenos Aires: Eudeba, 2011.

Brenes Tencio, Guillermo. «La alborada de la fotografía en Costa Rica: 1848-1869. Una contribución documental». Revista de Ciencias Sociales 113-114 (2006): 156-167. Acceso: 01 de junio de 2020. https://revistacienciassociales.ucr.ac.cr/images/revistas/RCS113_114/12B RENES.pdf

Camacho Morfín, Thelma. «Los álbumes de "El Buen Tono": fotografía y catolicismo social (México, 1894-1909)». Boletín americanista 71 (2015): 77-96. Acceso: 01 de junio de 2020. https://dialnet.unirioja.es/servlet/articulo?codigo=5503116

Castoriadis, Cornelius. La institución imaginaria de la sociedad. México: Fábula en Tusquets Editores, 2013.

Castoriadis, Cornelius. Poder, política, autonomía. Acceso: 01 de junio de 2020. https://omegalfa.es/downloadfile.php?file=libros/poder-politica-yautonomia.pdf.

del Castillo Troncoso, Alberto e Instituto Mora. «Los fotógrafos, la memoria y el 68 en México». Artelogie 7 (2015): 1-21. doi: 10.4000/artelogie.1102.

de las Heras, Beatriz y Víctor Mora. «Retratando el Madrid de la Guerra Civil. Santos Yubero en el Archivo Regional de la Comunidad de Madrid». Revista General de Información y Documentación 24-2 (2014): 343-371. doi: 10.5209/rev_RGID.2014.v24.v2.47404.

Díaz Bolaños, Ronald Eduardo. «El estudio de la historia de la meteorología a través de las crónicas de Visitas Pastorales en Costa Rica (1850-1921)». Revista Estudios especial (2019): 1-35. doi: 10.15517/RE.V0I0.36264. 
Diócesis de Alajuela. «Monseñor Dr. Antonio del Carmen Monestel y Zamora. I Obispo Diocesano (Del 14 de Agosto de 1921 al 8 de Octubre 1937)». Acceso: 01 de junio de 2020. http://www.diocesisdealajuela.org/mons.monestel.html

Giglioli, Giovanna. «Los intelectuales orgánicos en la teoría de Gramsci», Revista Reflexiones 46 (1996): 29-36. Acceso: 01 de junio de 2020. https://revistas.ucr.ac.cr/index.php/reflexiones/article/view/10907/10283

Grimson, Alejandro y Sergio Caggiano. «Respuestas a un cuestionario: posiciones y situaciones». En En torno a los Estudios Culturales. Localidades, trayectorias y disputas. Buenos Aires: Editorial Arcis/CLACSO, 2010.

Grossberg, Lawrence. «Identidad y estudios culturales, ¿no hay nada más que eso?» En Cuestiones de identidad cultural. Buenos Aires: Amorrortu, 2003.

Grossberg, Lawrence. «El corazón de los estudios culturales: Contextualidad, construccionismo y complejidad». Tabula Rasa 10 (2009): 13-48. Acceso: 01 de junio de 2020. http://www.scielo.org.co/pdf/tara/n10/n10a02.pdf

Grossberg, Lawrence. Estudios Culturales. Teoría política y práctica. Valencia: Letra Capital, 2010. Edición en PDF.

Instituciones de Investigaciones Sociales (UNAM). «Subalternidad». Acceso: 01 de junio de 2020.

http://conceptos.sociales.unam.mx/conceptos_final/497trabajo.pdf

Laclau, Ernesto y Chantal Mouffe. Hegemonía y estrategia socialista. Hacia una radicalización de la democracia. Madrid: Siglo XXI, 1987. Edición en PDF

Loaiza, Norma. «Amando Céspedes Marín: hombre-cumbre cuya obra es toda una brillante biografía». La Nación, 30 de octubre de 1966. Acceso: 01 de junio de 2020.

http://repositorio.sibdi.ucr.ac.cr:8080/jspui/handle/123456789/6787

Martín Nieto, Eva. «El valor de la fotografía. Antropología e imagen». Gazeta de Antropología 21 (2005): 1-4. Acceso: 01 de junio de 2020. https://www.ugr.es/ pwlac/G21_04Eva_Martin_Nieto.html

Martínez Villareal, Ronald. «Difusión histórica: La Expedición del Congreso de la República al cantón de Buenos Aires en 1923». Historia y Sociedad, noviembre de 2014. Acceso: 01 de junio de 2020. https://historiauned.net/profesor/editar/70-difusion-historica/315-difusionhistorica-la-expedicion-del-congreso-de-la-republica-al-canton-de-buenosaires-en-1923

Molina, Iván y Steven Palmer. The history of Costa Rica: brief, up to date and illustrated. San José: Editorial Universidad de Costa Rica. 2007. 
Mora Salazar, Orlando. El apogeo de la república liberal en Costa Rica: 18701914. San José: Editorial Universidad de Costa Rica, 2003.

Muñoz Jiménez, José. «Photography, memory and identity». Revista de Comunicación de la SEECI 49 (2019): 123-140. doi:

10.15198/seeci.2019.49.123-140.

Ovares, Flora y Margarita Rojas. La ciudad imaginada. San José: Editorial Costa Rica, 2015.

Panofsky, Erwin. El significado de las artes visuales. Madrid: Alianza Editorial, S.A, 1979. Edición en PDF.

Riego, Bernardo. «La imagen fotográfica como un mapa de significados: el caso del estudio fotográfico, un espacio para la representación social». Ponencia pronunciada en el Ayuntamiento de Girona, noviembre 1994.

Roa Gutiérrez, Flora y Alejandra Chaverri Álvarez. Las fotos de mi tata. Mario Roa: Costa Rica (1936-1946). Cartago: Editorial Tecnológica de Costa Rica, 2017.

Rodríguez Vega, Eugenio. Biografía de Costa Rica. San José: Editorial Costa Rica, 1980. Acceso: 01 de junio de 2020. https://es.scribd.com/read/299531694/Biografia-de-Costa-Rica\#

Tude de Sá, Alzira. «A imagem fotográfica como representação e documento: um estudo a partir das fotografias de objetos da sala de visitas do escritor Jorge Amado». Inf. \& Soc.:Est. 28 (2018): 91-108. Acceso: 01 de junio de 2020. https://periodicos.ufpb.br/index.php/ies/article/view/37898/19695 